\title{
Cloning, expression and functional activity of deoxyhypusine synthase from Plasmodium vivax James T Njuguna ${ }^{\dagger 1,2}$, Marwa Nassar ${ }^{\dagger 3}$, Achim Hoerauf ${ }^{1}$ and Annette E Kaiser*1,4
}

Address: ${ }^{1}$ Institute for Medical Microbiology, Immunology and Parasitology, D-53105 Bonn, Germany, ${ }^{2}$ International Livestock Research Institute (ILRI), Naivasha road, P.O. Box 30709, Nairobi, Kenya, ${ }^{3}$ Theodor Bilharz Research Institute, Warak El-Hadar, Kornish El Nile P.O. Box 30 Imbaba, Giza 12411, Egypt and ${ }^{4}$ The German University in Cairo, New Cairo City, Main Entrance of Al Tagamoa Al Khames, Egypt

Email: James T Njuguna - thuonjugunat@yahoo.com; Marwa Nassar - marwa_nassar21@yahoo.co.uk; Achim Hoerauf - hoerauf@parasit.meb.uni-bonn.de; Annette E Kaiser* - annette.kaiser@guc.edu.eg

* Corresponding author †Equal contributors

Published: 16 October 2006

BMC Microbiology 2006, 6:9| doi:|0.||86/|47|-2|80-6-9|
Received: 09 August 2006

Accepted: 16 October 2006

This article is available from: http://www.biomedcentral.com/I47I-2/80/6/9I

(C) 2006 Njuguna et al; licensee BioMed Central Ltd.

This is an Open Access article distributed under the terms of the Creative Commons Attribution License (http://creativecommons.org/licenses/by/2.0), which permits unrestricted use, distribution, and reproduction in any medium, provided the original work is properly cited.

\begin{abstract}
Background: Plasmodium vivax is the most widespread human malaria parasite. However, genetic information about its pathogenesis is limited at present, due to the lack of a reproducible in vitro cultivation method. Sequencing of the Plasmodium vivax genome suggested the presence of a homolog of deoxyhypusine synthase (DHS) from $P$. falciparum, the key regulatory enzyme in the first committed step of hypusine biosynthesis. DHS is involved in cell proliferation, and thus a valuable drug target for the human malaria parasite $P$. falciparum. A comparison of the enzymatic properties of the DHS enzymes between the benign and severe Plasmodium species should contribute to our understanding of the differences in pathogenicity and phylogeny of both malaria parasites.

Results: We describe the cloning of a I 368 bp putative deoxyhypusine synthase gene (dhs) sequence from genomic DNA of $P$. vivax PEST strain Salvador I (Accession number AJ549098) after touchdown PCR. The corresponding protein was expressed and functionally characterized as deoxyhypusine synthase by determination of its specific activity and cross-reactivity to human DHS on a Western blot.

The putative DHS protein from $P$. vivax displays a FASTA score of 75 relative to DHS from rodent malaria parasite, $P$. yoelii, and 74 relative to that from the human parasite, $P$. falciparum strain 3D7. The ORF encoding 456 amino acids was expressed under control of IPTG-inducible T7 promoter, and expressed as a protein of approximately $50 \mathrm{kDa}$ (theoretically $52.7 \mathrm{kDa}$ ) in E. coli BL2I DE3 cells. The N-terminal histidine-tagged protein was purified by Nickel-chelate affinity chromatography under denaturing conditions. DHS with a theoretical pl of 6.0 was present in both eluate fractions. The specific enzymatic activity of DHS was determined as $1268 \mathrm{U} / \mathrm{mg}$ protein. The inhibitor, $\mathrm{N}$-guanyl-I, 7-diaminoheptane (GC7), suppressed specific activity by 36 -fold. Western blot analysis performed with a polyclonal antihuman DHS antibody revealed cross-reactivity to DHS from P. vivax, despite an amino acid identity of $44 \%$ between the proteins.
\end{abstract}

Conclusion: We identify a novel DHS protein in the more benign malaria parasite, $P$. vivax, on the basis of specific enzymatic activity, cross-reactivity with a polyclonal antibody against human DHS, and amino acid identity with DHS homologs from the rodent malaria parasite, $P$. yoelii, and human $P$. falciparum strains. 


\section{Background}

Plasmodium vivax is the most widely distributed human malaria parasite and infects 70-80 million individuals per year worldwide. In most malaria endemic regions, $P$. falciparum and $P$. vivax infections coexist, and mixed infections are prevalent. Interactions between the two parasites determine the outcome of the disease and future therapeutic perspectives with regard to infection control. However, there is limited knowledge about the biology of the $P$. vivax parasite at present, due to the lack of an in vitro culture system.

To accelerate drug discovery for the more benign $P$. vivax, genome sequencing of the malaria parasite was performed to facilitate its annotation [1]. A transcriptome approach [2] was applied to study gene expression in the mixed erythrocytic stages of a $P$. vivax field isolate. Transcribed genes $(30 \%)$ displayed significant homology to those involved in metabolism and ribosomal proteins consistent with the trophozoite stage of the field strain.

Over recent years, increasing resistance of malaria parasites to therapy, and in particular, re-emergence of $P$. vivax infections, has increased the need to develop strategies of identifying novel drug targets. The polyamine pathway has been exploited for antiparasitic chemotherapy. Our research is focused on the formation of the novel amino acid hypusine, which involves two steps. In the first step, deoxyhypusine synthase (DHS) [EC 1.1.1.249] transfers an aminobutyl moiety from the triamine spermidine to a specific lysine residue in the eIF-5A (eukaryotic initiation factor 5A) precursor protein to form deoxyhypusine. In the second step, deoxyhypusine hydroxylase (DHH) [EC 1.14.9929] completes hypusine biosynthesis through hydroxylation. Deoxyhypusine modification is important for the viability of eukaryotic cells [3]. We have recently cloned two genes involved in hypusine biosynthesis from the malaria parasites $P$. falciparum and $P$. vivax, specifically, deoxyhypusine synthase (DHS) and eukaryotic initiation factor 5A (EIF-5A). To elucidate the phylogenetic relationship between deoxyhypusine synthase (DHS) proteins from both parasitic species, we clone the putative $d h s$ gene from $P$. vivax, and determine its specific enzymatic activity.

\section{Results}

Nucleotide sequence of a putative dhs gene from $P$. vivax The DHS amino acid sequence of $P$. falciparum strain NF 54 [4] was used to screen a library of expressed sequence (EST) tags from $P$. vivax strain PEST Salvador I. Based on the $5^{\prime}$ and 3 ' ends of dhs, two primers were constructed to amplify the 1368 bp sequence encoding 456 amino acids from the genomic DNA of Plasmodium vivax strain PEST Salvador I. The purified fragment was subcloned into pSTBlue-1AccepTor vector, and sequenced (accession number
AJ549098). The dhs gene has an AT content of 52\%, and a comparable GC content of $48 \%$.

The deduced amino acid sequence of the $P$. vivax protein was aligned with different putative DHS sequences from other Plasmodium species, i. e., P. falciparum Dd2 and 3D7 strains (Fig. 1, lanes 1 and 2), rodent malaria parasite $P$. yoelii (Fig. 1, lane 3), and Anopheles gambiae (Fig 1, lane 6). The $P$. vivax DHS amino acid sequence displayed FASTA scores of 74 and 73 relative to the $P$. falciparum strains Dd2 and 3D7, respectively. Notably, P. vivax DHS exhibits $66 \%$ amino acid identity between positions $1-236$ and $91 \%$ identity between positions 276-443 with the P. falciparum Dd2 strain.

There are several gaps in the amino acid stretches at positions 103, 240, 257 and 442 in the P. vivax DHS protein, which are absent in the $P$. falciparum homolog (numbering refers to the amino acid sequence from $P$. vivax). The $P$. vivax DHS protein has a FASTA score of 75 to its homolog from the rodent malaria parasite $P$. yoelii, while amino acid identity to the human DHS protein (Fig. 1, lane 5 ) is only $44 \%$. The lowest FASTA score of 49 was obtained between P. vivax and Anopheles gambiae DHS proteins (Fig. 1, lane 6)

\section{Expression of P. vivax DHS protein in E. coli cells and affinity purification}

The purified $P$. vivax DHS protein has a calculated molecular size of $50 \mathrm{kDa}$ (theoretically $52.7 \mathrm{kDa}$ ), and a pI value of 6.0. Initially, primers\# 1 and \#2 containing NdeI and BamHI restriction sites, respectively, were used for amplification of $d h s$, which was cloned into the pET15b vector for protein expression. Protein extracts prepared after $4 \mathrm{~h}$ of induction with IPTG exhibited a prominent band of approximately $50 \mathrm{kDa}$ on an SDS-PAGE gel (Fig. 2A, lane $3)$. In contrast, no band was detectable in the uninduced control culture (Fig. 2A, lane 2.) The recombinant protein was expressed with a six-histidine tag at the amino-terminus, allowing purification by Nickel-chelate affinity chromatography. Purified protein was analyzed by SDS-PAGE (Fig. 2). The protein was detected at $50 \mathrm{kDa}$ in both eluate fractions (Fig. 2, lanes 6 and 7).

\section{Modification of $\mathbf{P}$. vivax elF-5A precursor protein by $\mathbf{P}$. vivax deoxyhypusine synthase}

For the deoxyhypusine synthase assay, the purified eIF-5A precursor protein and DHS enzyme from $P$. vivax were applied [5]. The incorporation of radioactively labeled spermidine into the substrate precursor protein was assayed using a filter paper assay [14]. Purified samples were immediately used to determine specific enzymatic DHS activity. The average specific enzymatic activity from two experiments was $1268 \mathrm{U} / \mathrm{mg}$ protein suggesting that DHS protein from $P$. vivax is able to modify the eIF-5A 


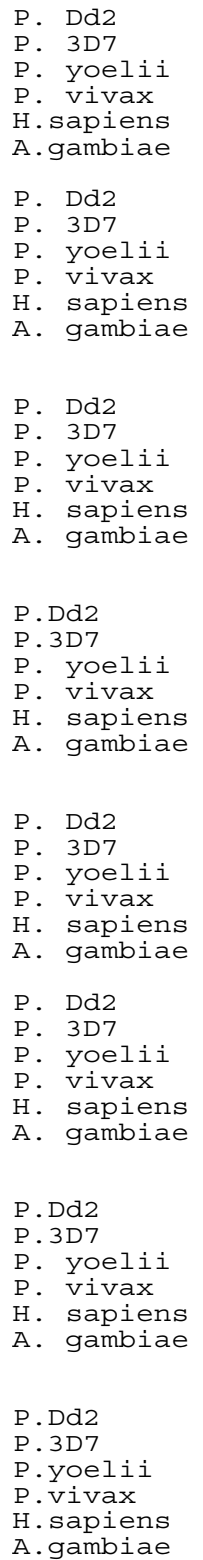

MVDHVSFIEVNKIRSDDECDADSHNEGDNIEDAKASVFVKSSLIPEKTDVVKGLNFDKEV 60 - MKEVMENYNR - - . - . - -MDGVFKEVNKIKNESE-TEDNDDNNGGINDAKSSVFVKSTKIPEKTDVVKGINFEKKV 57 MTNQGAFKEVNKIRSESD-DGESSDEKSGIEDAKSSVFVKSNKIPENTDVVKGINFEEEV 59 -MEGSLEREAPR - . . . . . . . . . - GRAAVLKHSSTLPPESTQVRGYDFNRGV 39 -MD--OSKEPTV - .................. AKEAVLQESSKLPENTPQIRGYDWNEGY 37

$\begin{array}{ccc}: & * \quad: \quad: & : \\ \text { DLHEFINNYKYMGFQATNLGISIDEINKMIYYKYKDENIKSEPNNENNLNCNNVSEDLNK } 120\end{array}$

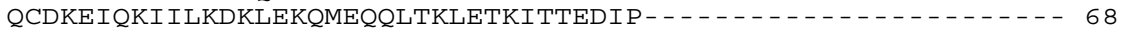

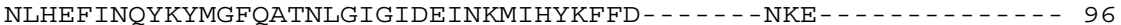
NLHOFVNOYKYMGFOATNLGIGIDEVNKMIHFKYAE - - . - . - GGEGTQDGH - - DNDHDQ 110 NYRALLEAFGTTGFQATNFGRAVQQVNAMIEKKLE- - - - - - - - - - - PLSQDE 80 SYEKLFSSYAHSGFQATNLGKAIEEVNKMVRFFLPR - . - . - . . . - RVPLAEDK 81 $:: \quad: \quad:::$

DOENHLYHYEKKKKSCI IWLSFTSNMISSGLREIFVYLAKNKFIDVVVTTAGGIEEDIIK 180 TCVCEKSLADKVEKGCLKCGYGLGTVAPTVGLIGSVAVNVWKTTEIAAAIAAAEKTGAAQ 128 DIKNDSITYDNKKK - CMIWLSFTSNMISSGLREIFVYLAKNNYIDVVVTTAGGIEEDLIK 155 DSDDERQALPKKKK-CLIWLSFTSNMISSGLREIFVYLAKKKFIDVVVTTAGGVEEDIIK 169 DOHGDLTOSRRPLTSCTIFLGYTSNLISSGIRETIRYLVOHNMVDVLVTTAGGVEEDLIK 140 LDOYEEDEFIKRKNSCTIFLGYTSNMVSAGVRETIRFLVOHRMVDCIVTTAGGVEEDLIK 141

CFSNTYIGDFNLNGKKLRKKGWNRIG-NLIVPNDNYCKFEDWLQPILNKMLHEQNEKNEQ 239 GAAAGLKAGVDAVITGLKERGVGLLCPKLLES IGDTIHYTDDGO - - IAKI ILENLSTN - - 184 CFSKTYLGDFNLNGSKLRKKGWNR IG-NLIVPNDNYCMFEDWVOPLLDKILREONEKNEE 214 CFSKTYLGDFNLNGKKLRKKGWNRIG-NLIVPNDNYCKFEDWLQPLLNKMLHEQNRKNEE 228 CLAPTYLGEFSLRGKELRENGINRIG-NLLVPNENYCKFEDWLMP ILDQMVMEQNIEG - - 197 CLAPTYLGSFELAGRELRERGINRIG-NLLVPNENYCKFENWVIPILDEMLAEQKSNG-- 198

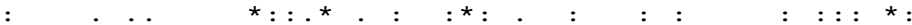

MFLKKLEKRKKKYNNNKNKNDNNNDNDNVWGNEKNDQNENQYNQGQESFKKDSNIYTNDV 299

LFLRKLEKRKKK - .

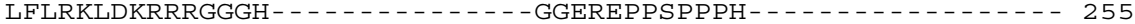

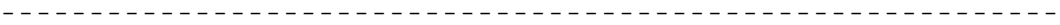

- - - - - - - - - - - -

SNKKNHINNYINNYDSDSDDQCDMYYLSPSEFINTLGKEINDESSLIYWCYKNDIPIFCP 359 - - KSNQQ - - - -YLSFDEEEDDMFYLSPSELINRLGKEINDETSLLYWCYKNNIPVFCP 289 - - TPHAPSPPSPCDSSDEDESDMFYLSPSEFIDKLGEEINDESSLIYWCHKNDIPVFCP 312 - - - - - - - - - - - AKWTPSKMIARLGKEINNPESAYYWAQKNHIPVFSP 233

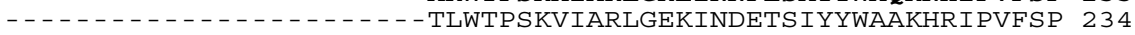

243

GLTDGSLGDNLFLHNYGKKI KNNLILDIVKDIKKINSLAMNCEKSGIIILGGGLPKHHVC 419

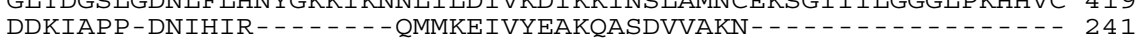
GLTDGSLGDNLFFHNYGKKMKNNLILDIVKDIKKINSLALKCHKSGIIVLGGGLPKHHVC 349 GLTDGSLGDNLFFHNYGKKI KNNLILDIVKDIKKINSLALNCKKSGIIILGGGLPKHHVC 372 ALTDGSLGDMIFFHSYKN - - PGLVLDIV _ . $\ldots \ldots \ldots$ ALTDGSLGDMMYFHSFRN - - PGLVVDIVSDLRRLNTMAVKAVQSGIIIVGGGVIKHHIC 291 . . $\quad$ : : : $::$ : $*$ * 316 329 342

NANLMRNGADFAVYVNTASEYDGSDSGANTTEALSWGKI KYGOTNNHVKVFGDATILFPL 479 _... - . - . NANLMRNGADFAVYVNTANEYDGSDSGANTTEALSWGKLKSGNNISHVKVFGDATILFPL 409 NANLMRNGADFAVYVNTANEYDGSDSGANTTEALSWGKIKAGHTNNHVKVFGDATILFPL 432 ............ EAQEFDGSDSGARPDEAVSWGKIRVDAQP - VKVYADASLVFPL 301 NANLMRNGADFSVFVNTASEYDGSDSGARPDEAVSWGKIKKDATP - -VKVYAEASLVFPI 349

P.falciparum Dd2

P. falciparum3D7

P.yoelii

P. vivax

Homo sapiens

Anopheles gambiae

\section{Figure I}

Amino acid alignment between a putative DHS protein from $P$. vivax and two different $P$. falciparum strains, the rodent malaria parasite $P$. yoelii, human and the mosquito Anopheles gambiae. Numbering refers to DHS in the two P. falciparum species. Lane I: P. falciparum strain Dd2 (accession number AF290977); lane 2: P. falciparum strain 3D7 (accession number NC 004317); lane 3: P. yoelii (XM-724232); lane 4: P. vivax (AJ549098); lane 5: human (U26266), lane 6: Anopheles gambiae (XM-316567). Gaps (-) were introduced to obtain maximum alignment. Arterisks label amino acid identities, colons (:) and dots (.) label amino acid similarities. The spermidine binding site (243-329 refering to human DHS numbering) is marked by bold amino acids. The NAD binding site from serine 105 to aspartic acid 342 is marked in bold letters. The active center of the DHS protein from glutamine 324 to lysine 329 is bolded black. 
A)

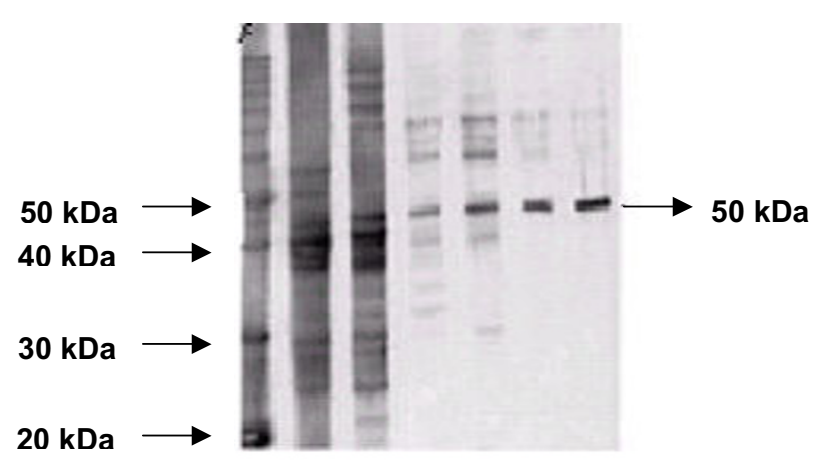

$\begin{array}{lllllll}1 & 2 & 3 & 4 & 5 & 6 & 7\end{array}$

B)

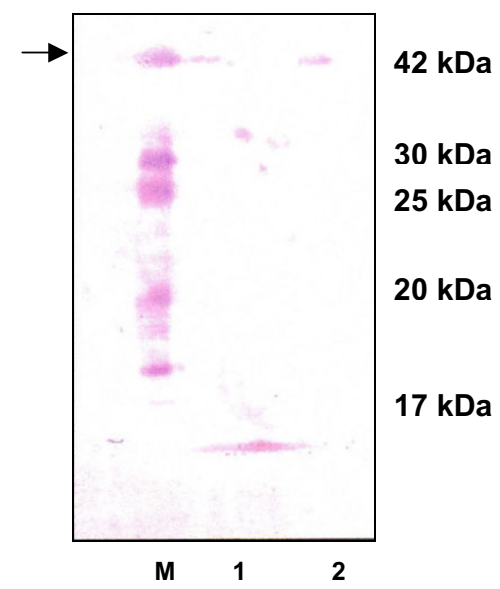

Figure 2

A: Expression and purification of recombinant putative six histidine tagged deoxyhypusine synthase from $P$. vivax by Nickel-chelate chromatography. $12 \%$ SDS PAGE protein gel: I) protein marker: $10 \mathrm{kDa}$ ladder; 2) non induced bacterial cell lysate 3 ) induced bacterial cell lysate with 100 mM IPTG after 4 hours of induction; 4 and 5) wash fractions obtained after purification; 5 and 6) eluate fractions of purified putative deoxyhypusine synthase. B: Western Blot analysis of the expressed, purified $P$. vivax DHS protein. lane 0) standard molecular size marker (Roth); lane I) protein extract of purified DHS protein from $P$. vivax by Nickel-chelate chromatography. lane 2) protein extract of purified human DHS protein. The blot was probed with a I: 800 diluted polyclonal antiserum against human DHS. precursor protein (Table 1, column A). In a control experiment, no specific enzymatic activity was detected when water was used instead of DHS (Table 1, column B). The specific enzymatic activity of $P$. vivax DHS was suppressed 36-fold with the inhibitor $\mathrm{N}$-guanyl-1,7-diaminoheptane (GC7) (Table 1, column C).

\section{Plasmodium vivax deoxyhypusine synthase shows cross- reactivity to its human homolog}

To determine whether a polyclonal antibody against human DHS recognized the corresponding protein from $P$. vivax, the Nickel-chelate purified protein was subjected to Western blot analysis (Fig. 2B, lane 1). As a positive control, we used purified human DHS protein (Fig. 2B, lane 2). The antibody specifically recognized human DHS protein with a molecular size of $41 \mathrm{kDa}$ (Fig. 4, lane 2), and cross-reacted with the Plasmodium vivax DHS protein (Fig. 2B, lane 1).

\section{Discussion}

Reduced in vitro susceptibility [6] of field isolates from Plasmodium falciparum strains to artemeter derivatives is an alarm signal necessitating the rapid deployment of drug combinations. There is an urgent need to elucidate the genome of human malaria parasites. In 2000, after the completion of the $P$. falciparum genome project, the sequencing of expressed sequence tags (EST) from the human malaria parasite P. vivax of Salvador PEST strain I, isolated from a malaria patient from Thailand, was initiated. No information about this parasite is available to date. In contrast to P. falciparum, it infects reticulocytes, which are young immature erythrocytes. Due to the lack of a reproducible continuous in vitro culture system [7], detailed molecular analyses were not possible.

Recently, we exploited the biosynthetic pathway of the generation of the novel amino acid, hypusine, in the human malaria parasite P. falciparum [8]. Two proteins, i.e., DHS and eukaryotic initiation factor 5A (eIF-5A) involved in the formation of deoxyhypusine, the first committed step in the hypusine biosynthetic pathway, are potential new drug targets in Plasmodium falciparum [9]. To identify the phylogenetic homologs of the dhs gene in different Plasmodium species, a library of Plasmodium vivax expressed sequence tags was screened for a DHS homolog from $P$. falciparum. The putative DHS sequence from $P$. vivax is encoded by a 1386 bp nucleic acid sequence, with the most significant FASTA scores of 75 to $P$. yoelii and 74 to $P$. falciparum strain 3D7. These results are in agreement with initial comparative analyses of the $P$. vivax genome with the other related Plasmodium species, which revealed significant conservation of gene synteny between the different species within chromosome cores, in contrast to subtelomeric regions displaying reduced homology [10]. 
Table I: Determination of DHS activity from $P$. vivax by elF-5A modification

\begin{tabular}{lll}
\hline incubation temp. $37^{\circ} \mathrm{C}$ & incubation temp. $37^{\circ} \mathrm{C}$ & incubation temp. $37^{\circ} \mathrm{C}$ \\
\hline elF5A lys & Water & $50 \mu M \mathrm{GC7}$ \\
${ }^{14}[-\mathrm{C}]-$-spermidine & ${ }^{14}[-\mathrm{C}]$-spermidine & $14[-\mathrm{C}]-$ spermidine \\
$1268 \mathrm{U}$ DSS/mg protein & n.d. U DHS/mg protein & $35 \cup \mathrm{DHS} / \mathrm{mg}$ protein \\
P. vivax DHS & P. vivax DHS & P. vivax DHS \\
A & B & C \\
\hline
\end{tabular}

column A) complete enzymatic assay B) control: DHS enzyme was substituted by water C) inhibition of DHS by the inhibitor GC7 (50 $\mu$ M).

$P$. vivax DHS displays striking amino acid sequence identity to its homolog from P. falciparum. Notably, $89 \%$ amino acid identity is observed between $P$. vivax DHS protein (Fig. 1, lane 4) and the human homolog between residues 290-308 (human DHS numbering) (Fig. 1, lane 5). However, several gaps appear in the $P$. vivax protein sequence at positions 103, 240, 257 and 442, which are absent in the Plasmodium falciparum homolog.

The most significant differences between human and Plasmodium DHS homologs are evident in the spermidine binding site (residues 243-342, human DHS numbering), although the active site is highly conserved. The active site includes a conserved region of six amino acids from Glu 323 to Lys 329 (human DHS numbering) (Fig. 1) $[11,12]$. Asp 316, one of the charged amino acids at the bottom of the active site tunnel responsible for binding to spermidine and the $\mathrm{GC}_{7}$ inhibitor, is highly conserved in DHS proteins in Plasmodium [13]. Moreover, in both DHS proteins, Gly 314 is within hydrogen-binding distance of the guanidinium group [13].

The NAD-binding site (positions 105-342, human DHS numbering) is strongly conserved between the different Plasmodium species and their human homologs. However, a stretch of 85 amino acids mainly comprising asparagine in this site is missing in DHS homologs from Plasmodium.

To confirm the function of $P$. vivax DHS, we determined its specific enzymatic activity in modification of eukaryotic translation initiation factor, eIF-5A, by incorporation of the aminobutyl-moiety of ${ }^{14}[-\mathrm{C}]$-spermidine as a substrate (Table 1, column A). Specific enzymatic activity was determined as $1268 \mathrm{U} / \mathrm{mg}$ protein, which was 9-fold less than that calculated by Molitor and colleagues (2004) [14], who used human DHS protein for the modification of eIF-5A from $P$. falciparum. In a control experiment with water instead of DHS from $P$. vivax, no specific enzymatic activity was detected.

In a parallel inhibition experiment, the most commonly used competitive inhibitor of DHS, N1-guanyl-1,7-diaminoheptane (GC7) (Table 1, column C), was employed. GC7 inhibits DHS in a competitive manner by binding to its active site [15], as observed in crystallized form II that was recently obtained for the complex of DHS and GC7. This inhibitor reduced specific enzymatic activity by $36-$ fold (Table 1, column C).

While the amino acid identity between human and Plasmodium vivax DHS is only $44 \%$, we detected cross-reactivity between a polyclonal antibody raised against the human DHS enzyme and the expressed Nickel chelatepurified protein (Fig. 2B, lane 1) from P. vivax, suggesting that the anti-DHS antibody recognizes specific epitopes present in both proteins.

\section{Conclusion}

The putative $P$. vivax DHS protein consists of 456 amino acids with significant FASTA scores of 75 to $P$. yoelii and 74 to $P$. falciparum strain 3D7 DHS proteins. A specific DHS enzymatic activity assay with ${ }^{14} \mathrm{C}$-labeled spermidine as the substrate and inhibition by N-guanyl-1,7-diaminoheptane (GC7) confirmed functional activity. Moreover, the DHS protein from P. vivax cross-reacted with a polyclonal antibody against anti-human DHS. Further biochemical characterization analyses of the P. vivax DHS protein are currently underway.

\section{Methods \\ Amplification of dhs from genomic DNA of $P$. vivax strain PEST Salvador I}

The amplification reaction comprised 89 ng genomic DNA of P. vivax strain PEST Salvador I, 200 pmol forward primer 1\# ATG ACG AAC CAA GGG GCT TTT and reverse primer 2\# TCA CCT GAG CTG CGC TTC ACC, $10 \mathrm{mM}$ dNTP, $75 \mathrm{mM} \mathrm{MgCl}, 2 \mu \mathrm{l} 10$ fold PCR buffer and $5 \mathrm{U}$ Taq polymerase (Qiagen) in a total volume of $20 \mu \mathrm{l}$. Amplification was performed using a temperature profile of $94^{\circ} \mathrm{C}$ for $5^{\prime}, 94^{\circ} \mathrm{C}$ for $1^{\prime}, 60^{\circ} \mathrm{C}$ for $1^{\prime}, 72^{\circ} \mathrm{C}$ for $1^{\prime}$ for 30 cycles, and $72^{\circ} \mathrm{C}$ for $10^{\prime}$, generating a product of $1386 \mathrm{bp}$. The PCR product was subcloned into the pSTBlue-1 AccepTor Vector (Novagen). Positive recombinant clones were identified by dideoxynucleotide sequencing (MWG Biotech, Munich). 
Expression and purification of DHS protein from P. vivax by Nickel-chelate affinity chromatography

After purification (Quiaex), the 1386 bp fragment was subcloned into petBlue-1 vector (Novagene), and transformed for expression in Tuner ${ }^{\mathrm{TM}}$ (DE3) pLacI cells (Novagen). Insertion of the open reading frame in the correct orientation was confirmed by sequencing (MWG Biotech, Munich). Cells with an optical density of 0.6-1.0 at $\mathrm{OD}_{600}$ were resuspended in $3 \mathrm{ml}$ of fresh Luria Bertani (LB medium) supplemented with $0.5-1.0 \%$ glucose and 100 $\mu \mathrm{g} / \mathrm{ml}$ ampicillin were used to inoculate $100 \mathrm{ml} \mathrm{LB}-$ medium with the same concentration of supplements at $37^{\circ} \mathrm{C}$ until $\mathrm{OD}_{600}$ 0.5-1.0. Prior to induction, cells were split into two $50 \mathrm{ml}$ cultures. One culture was supplemented with $500 \mu \mathrm{l}$ of $100 \mathrm{mM}$ IPTG, while the other served as the uninduced control. Protein extracts were prepared $4 \mathrm{~h}$ after induction by centrifugation, lysed, heated at $100^{\circ} \mathrm{C}$, and run on a $12 \%$ SDS polyacrylamide gel at $100 \mathrm{~V}$. The $10 \mathrm{kDa}$ protein ladder (Gibco BRL) and RainBow Marker were used as molecular weight markers.

P. vivax DHS protein was expressed under control of the T7-inducible promoter in pET15b vector (Novagene), which allows purification of $6 x$ His-tagged proteins. PSTBlue 1 AccepTorVector (Novagene) containing the dhs gene was used as a template for subcloning the full-length dhs sequence by amplification with expression primers (forward 1\# 5'-AAC CCC ATA TGA CGA ACC AAG GGG CTT TT-3' containing an Nde I restriction site (underlined) and a Bam HI restriction site (underlined; reverse 2 \# 5'AAAA GGA TCC TCA CCT GAG CTG CGC TTC-3'), respectively. Protein purification was performed by Nickel chelate affinity chromatography under denaturing conditions, according to the manufacturer's protocol (Qiagen).

\section{Enzymatic activity assay of deoxyhypusine synthase expressed from $\mathbf{P}$. vivax}

Deoxyhypusine synthase activity was measured by the incorporation of $40 \mathrm{mM}$ [14-C] spermidine into eIF-5A precursor protein. A total volume of $50 \mu \mathrm{l}$ consisted of 83.3 mM Nickel affinity-purified eIF-5A, NAD $+1 \mathrm{mM}, 0.1$ $\mathrm{M}$ glycine-NaOH buffer, $\mathrm{pH}$ 9.5, $1 \mathrm{mM}$ dithiothreitol and Nickel-affinity purified DHS enzyme (1-5 $\mu \mathrm{g})$. DHS activity assay was performed after a second buffer exchange step on a NAP TM5 column (Amersham Pharmacia). Assays were incubated for $2 \mathrm{~h}$ at $37^{\circ} \mathrm{C}$. The reaction was terminated by adding $10 \mathrm{ml}$ of $1 \mathrm{M}$ potassium phosphate, pH 6.3, with $60 \mathrm{mM}$ spermidine. The incubation mixture was absorbed onto a Whatman No.3 MM paper disc, and developed using the method of Sasaki et al. (1996) [16].

\section{Western blot analysis of DHS from P. vivax}

Western blot analysis was performed using the sandwich method in a semi-dry transfer electroblotting apparatus (Fisher Scientific) for $1 \mathrm{~h}$ at $25 \mathrm{~V}$. After $3 \mathrm{~h}$ of induction, protein extracts were transferred to a nitrocellulose membrane in transfer buffer ( $12 \mathrm{mM}$ Tris, $96 \mathrm{mM}$ glycine and $20 \%$ methanol). The primary polyclonal antibody against human DHS protein was kindly provided by MH. Park (Oral and Pharyngeal Cancer Branch, National Institute of Health, Bethesda). The polyclonal human anti-DHS antibody was diluted (1: 800) in TBS (10 mM Tris, $15 \mathrm{mM}$ $\mathrm{NaCl}$ ) buffer, incubated for $1 \mathrm{~h}$ at room temperature, and washed twice with TBS-Tween buffer. The primary antibody was detected with a secondary immunopure rabbit anti-mouse- IgG- alkaline phosphatase conjugate (Pierce) at a dilution of 1: 10.000. The membrane was washed with TBS-Tween buffer, and detected with nitroblue tetrazolium phosphate (5\% in 70\% dimethylformamide) and 5-bromo-4-chloro-3-indolylphosphate $(5 \%$ in $100 \%$ dimethylformamide) in alkaline phosphatase buffer (100 $\mathrm{mM}$ Tris-Cl, $100 \mathrm{mM} \mathrm{NaCl}, 5 \mathrm{mM} \mathrm{MgCl}_{2}$ ).

\section{Authors' contributions}

JTN was responsible for cloning and, in part, expression experiments on the dhs gene. MN performed experiments on specific enzymatic activity and inhibition. AEK supervised the work, organized financial support, and prepared the manuscript. AH critically appraised the manuscript.

\section{Acknowledgements}

The work was supported, in part, by grants to Dr. August and Annie Lesmüller Stiftung, Munich, Germany.

\section{References}

I. Carlton J, Dame J: The Plasmodium vivax and P. berghei gene sequence tag projects. Parasitol Today 2000, 10:409.

2. Cui L, Fan Q, Hu Y, Karamycheva SA, Quackenbush J, Khuntirat B, Sattabongkot J, Carlton JM: Gene discovery in Plasmodium vivax through sequencing of ESTs from mixed blood stages. Mol Biochem Parasitol 2005, I 44: I-9.

3. Park MH: The Post-Translational Synthesis of a PolyamineDerived Amino Acid, Hypusine, in the Eukaryotic Translation Initiation Factor 5A (elF5A). J Biol Chem (Tokyo) 2006, 139:161-69.

4. Kaiser A, Gottwald A, Maier W, Seitz HM: Targeting enzymes involved in spermidine metabolism of parasitic protozoa -a possible, new strategy for antiparasitic treatment. Parasitol Res 2003, $91: 508-16$.

5. Studier FW, Moffat BA: Use of bacteriophage T7 RNA polymerase to direct selective high-level expression of cloned genes. J Mol Biol 1986, I 89: I I3-30.

6. Jambou R, Legrand E, Niang M, Khim N, Lim P, Volney B, Ekala MT, Bauchier C, Esterre P, Fandeur T, Mercereau-Puijalon O: Resistance of Plasmodium falciparum field isolates to in-vitro artemether and point mutations of the SERCA-type PfATPase6. Lancet 2005, 366: 1960-63.

7. Golenda CF, Li J, Rosenberg R: Continuous in vitro propagation of the malaria parasite Plasmodium vivax. Proc Natl Acad Sci 1997, 94:6786-91.

8. Kaiser A, Gottwald A, Wiersch C, Maier W, Seitz HM: Effect of drugs inhibiting spermidine biosynthesis and metabolism on the in vitro development of $\boldsymbol{P}$. falciparum. Parasitol Res 200I, 87:963-72.

9. Kaiser A, Gottwald C, Wiersch C, Maier W, Seitz HM: Spermidine metabolism in parasitic protozoa-a comparison to the situation in prokaryotes, viruses, plants and fungi. Folia Parasitol 2003, 50:3-18. 
10. Carlton J, Silva J, Hall N: The genome of model malaria parasites, and comparative genomics. Curr Issues Mol Biol 2005, 7:23-37.

II. Yan YP, Tao Y, Chen KY: Molecular cloning and functional expression of human deoxyhypusine synthase cDNA based on expressed sequence tag information. Biochem J 1996, 3 I 5:429-434.

12. Joe YA, Wolff EC, Lee YB, Park MH: Enzyme-substrate intermediate at a specific lysine residue is required for deoxyhypusine synthesis. The role of Lys329 in human deoxyhypusine synthase. J Biol Chem (Tokyo) 1997, 272:32679-32685.

13. Umland TC, Wolff TC, Park MH, Davies DR: A new crystal structure of deoxyhypusine synthase reveals the configuration of the active enzyme and of an enzyme NAD inhibitor ternary complex. J Biol Chem 2004, 279:28697-28705.

14. Molitor IM, Knobel S, Dang C, Spielmann T, Allera A, König GM: Translation initiation factor elF-5A from Plasmodium falciparum. Mol Biochem Parasitol 2004, 1 37:65-74.

15. Liao DI, Wolff EC, Park MH, Davies DR: Crystal structure of the NAD complex of human deoxyhypusine synthase: an enzyme with a ball-and-chain mechanism for blocking the active site. Struct 1998, 6:23-32.

16. Sasaki K, Abid R, Miyazaki M: Deoxyhypusine synthase gene is essential for cell viability in the yeast Saccharomyces cerevisiae. FEBS Letters 1996, 384:I5I-I54.

Publish with Bio Med Central and every scientist can read your work free of charge

"BioMed Central will be the most significant development for disseminating the results of biomedical research in our lifetime. "

Sir Paul Nurse, Cancer Research UK

Your research papers will be:

- available free of charge to the entire biomedical community

- peer reviewed and published immediately upon acceptance

- cited in PubMed and archived on PubMed Central

- yours - you keep the copyright 